\title{
Positive degree-day factors for ablation on the Greenland ice sheet studied by energy-balance modelling
}

\author{
Roger J. BRaIthwaIte \\ Gronlands Geologiske Undersogelse, DK-1350 Kobenhavn K, Denmark
}

\begin{abstract}
Ice ablation is related to air temperature by the positive degree-day factor. Variations of the positive degree-day factor in West Greenland are studied using an energy-balance model to simulate ablation under different conditions. Degree-day factors for simulated and measured ice ablation at Nordbogletscher and Qamanârssûp sermia agree well with values around $8 \mathrm{~mm} \mathrm{~d}^{-1}{ }^{\circ} \mathrm{C}^{-1}$. Degree-day factors for snow are less than half those for ice. Energy-balance modelling shows that degreeday factors vary with summer mean temperature, surface albedo and turbulence but there is only evidence of large positive degree-day factors at lower temperatures and with low albedo $(0.3)$. The greatest effect of albedo variations $(0.3-0.7)$ is at lower temperatures while variations in turbulence have greater effect at higher temperatures. Current models may underestimate runoff from the Greenland ice sheet by several tenths because they use a degree-day factor for melting ice that is too small for the colder parts of the ice sheet, i.e. the upper ablation area and the northerly margin.
\end{abstract}

\section{INTRODUGTION}

The importance of air temperature for glacier melting is well known. In particular, the melting of snow or ice during any period is often assumed proportional to the sum of all temperatures above the melting point at the same place and during the same period, i.e. the positive degreeday sum. The factor linking ablation to this temperature sum is the positive degree-day factor. The positive degreeday factor is usually treated as a constant but here I examine its variations, both for observed ablation and for ablation calculated by an energy-balance model.

The degree-day approach was first used in the Alps by Finsterwalder and Schunk (1887), tested by Braithwaite and Olesen $(1985,1989)$ under Greenland conditions, modified by Reeh (1991) to calculate melting over the whole Greenland ice sheet, and used in ice-dynamics modelling by Huybrechts and others (1991) and Letréguilly and others (1991).

The positive degree-day factor involves a simplification of complex processes that are more properly described by the energy balance of the glacier surface and overlaying atmospheric boundary layer. This means that the positive degree-day factor itself must depend upon the energy balance (de Quervain, 1979; Ambach, 1988), making a universal factor implausible. Melting snow has a lower positive degree-day factor than melting ice under otherwise identical conditions because of lower energy fluxes (Hoinkes and Steinacker, 1975; Braithwaite and Olesen, 1988), but even ice must have different factors for different energy-balance regimes.

The present study uses data from Nordbogletscher and Qamanârssûp sermia in West Greenland (Fig. 1). Ablation was measured almost every day at stake 53 on Nordbogletscher (at $880 \mathrm{~m}$ a.s.l. and $61^{\circ} 28^{\prime} \mathrm{N}$ ) and at stake 751 on Qamanârssûp sermia $(790$ ma.s.l. and $64^{\circ} 28^{\prime} \mathrm{N}$ ) (Olesen and Braithwaite, 1989). An energybalance model was also used to calculate ablation from simple climate data (air temperature, humidity, wind

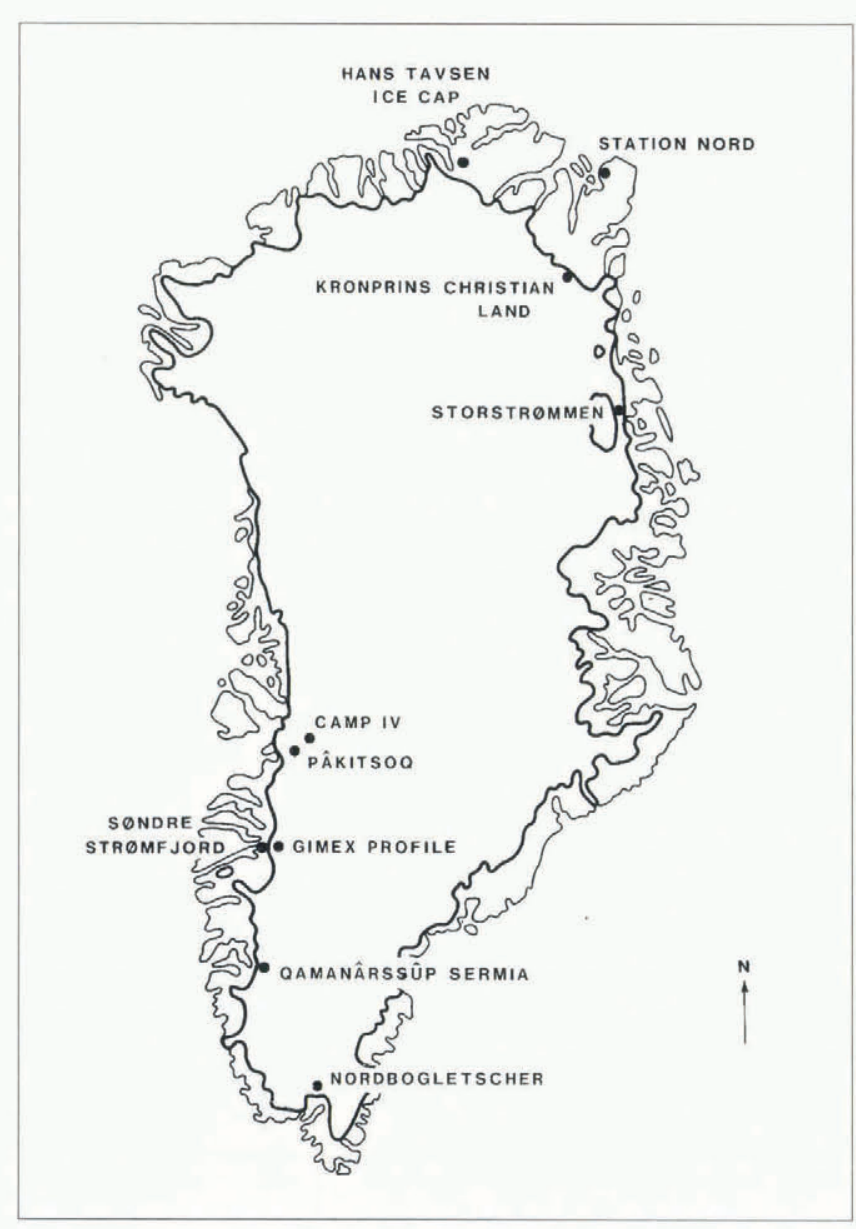

Fig. 1. Locations of glaciological studies in Greenland referred to in the text. 
speed, sunshine duration, and incoming short-wave radiation). These data were observed at the base camps close to the stakes where ablation was measured. The calculated and measured ablation data cover the JuneAugust period for six summers at Nordbogletscher $(415 \mathrm{~d}$ in 1979 -83) and seven summers at Qamanârssûp sermia $(512 \mathrm{~d}$ in $1980-86)$.

\section{DEGREE-DAY MODEL}

The treatment follows Braithwaite and Olesen (1989). Daily ablation $a_{t}$ is proportional to the daily mean temperature $T_{t}$ (in ${ }^{\circ} \mathrm{C}$ ) as long as the temperature is at or above the melting point:

$$
a_{t}=\alpha+\beta T_{t}+\varepsilon_{t} \quad T_{t} \geq 0^{\circ} \mathrm{C}
$$

where $\alpha$ and $\beta$ are parameters and $\varepsilon_{t}$ is a random error. Physically $\alpha$ represents the melting with an air temperature of $0^{\circ} \mathrm{C}$ while $\beta$ describes the increase of ablation with temperature. Equation (1) implies that part of the ablation energy is controlled by air temperature and part is independent. A variable $H_{t}$ is defined such that:

$$
\begin{aligned}
H_{t} & =1.0 & & T_{t} \geq 0^{\circ} \mathrm{C} \\
& =0.0 & & T_{t}<0^{\circ} \mathrm{C}
\end{aligned}
$$

The total ablation $A$ over an $N \mathrm{~d}$ period is given by:

$$
\begin{gathered}
t=N \\
A=\quad \Sigma H_{t} a_{t} \\
t=1
\end{gathered}
$$

Combining Equations (1) and (3) gives:

$$
\begin{aligned}
& \begin{array}{rl}
t=N & t=N \\
A=\alpha \quad & \Sigma H_{t}
\end{array} \\
& t=1 \quad t=1
\end{aligned}
$$

The first summation equals the number of days $N^{*}$ with temperatures at or above the melting point, and the second summation is the positive degree-day sum PDD for the $N$ d period. The summation of the random error term $\varepsilon_{t}$ is assumed to be zero. The mean daily ablation rate for the $N$ d period $A / N$ is given by:

$$
A / N=\alpha\left(N^{*} / N\right)+\beta(\mathrm{PDD} / N)
$$

where $N^{*} / N$ is the frequency of melting temperatures during the period and $\mathrm{PDD} / N$ is the mean of positive temperatures in the period. These terms can be calculated from mean temperature, e.g. for a month, by assuming that temperatures are randomly distributed around the mean temperature (Braithwaite, 1985). By definition, the positive degree-day factor is:

$$
k=A / \mathrm{PDD} .
$$

Combination of (5) and (6) gives $k$ as a function of $\alpha$ and $\beta$ :

$$
k=\alpha\left(N^{*} / \mathrm{PDD}\right)+\beta .
$$

The positive degree-day factor $k$ is not generally the same as the slope $\beta$ as (carelessly) implied by Braithwaite and Olesen (1989). The variations of $N^{*}$ and PDD with monthly mean temperature are shown in Table 1 . The ratio $N^{*} / \mathrm{PDD}$ decreases with increasing temperature so the effect of $\alpha$ on the degree-day factor $k$ is progressively reduced, and $k$ tends to $\beta$ in the limit of high temperatures.

Table 1. Days with melting $\left(N^{*}\right)$ and positive degree-day sum $(P D D)$ versus monthly mean temperature using the probability model of Braithwaite (1985). All figures refer to a 31 d month

\begin{tabular}{rrrr}
\hline$T$ & $N^{*}$ & $\begin{array}{r}P D D \\
\mathrm{degd}\end{array}$ & $\begin{array}{c}N^{*} / P D D \\
{ }^{\circ} \mathrm{C}\end{array}$ \\
\hline-6.0 & 2 & 3 & 0.63 \\
-4.0 & 5 & 10 & 0.50 \\
-2.0 & 9 & 24 & 0.39 \\
0.0 & 15 & 49 & 0.31 \\
2.0 & 22 & 86 & 0.25 \\
4.0 & 26 & 134 & 0.19 \\
6.0 & 29 & 189 & 0.15 \\
8.0 & 30 & 249 & 0.12 \\
10.0 & 31 & 310 & 0.10 \\
\hline
\end{tabular}

The degree-day model rests upon a claimed relation between daily ablation and daily mean temperature that is shown in Figure 2 using data from Qamanârssûp sermia as an example. There is a fairly strong correlation between ablation and temperature $(r=0.78$ with sample size 512$)$, but the relation is by no means perfect. The considerable scatter is due to the influence of other factors than temperature, as well as the effect of measurement errors, which have a standard deviation of about \pm 10 to $\pm 20 \mathrm{~mm} \mathrm{~d}^{-1}$ for daily data. Negative values of ablation in Figure 2 are clearly caused by errors.

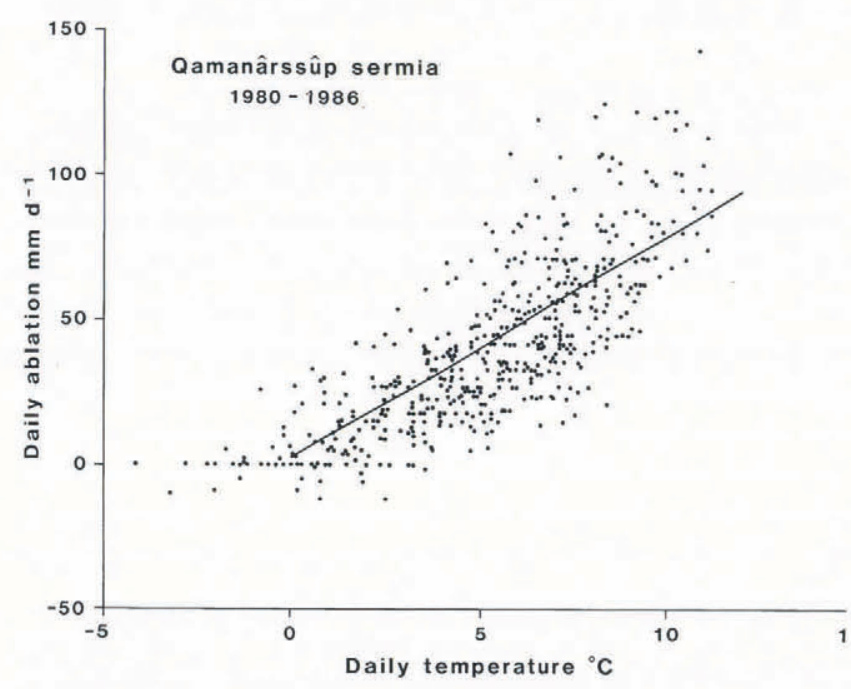

Fig. 2. Measured daily ablation versus daily mean temperature, Qamanârssûp sermia. 
The intercept $\alpha$ of the regression line in Figure 2 is slightly positive $\left(+3 \mathrm{~mm} \mathrm{~d}^{-1}\right)$ so there is a general tendency here for ablation to occur even when air temperature is $0^{\circ} \mathrm{C}$. A positive $\alpha$ in Equation (7) means that the positive degree-day factor $k$ decreases with increasing temperature in agreement with Ambach (1988).

The above conclusion should be treated cautiously because positive $\alpha$ is by no means self-evident for several reasons. First, the surface energy balance at $0^{\circ} \mathrm{C}$ is quite complex (Kuhn, 1987), although one might expect $\alpha$ to be positive if there is enough short-wave radiation, due to low albedo, to offset the relative lack of turbulent-heat flux. Secondly, the use of daily mean temperature for the correlation implies a bias towards positive $\alpha$ because air temperatures will be above $0^{\circ} \mathrm{C}$ for part of a day and, all other things equal, there will be surface melting even if the daily mean temperature is zero (Arnold and MacKay, 1964; Kuusisto, 1984). Thirdly, the intercept in Figure 2 is not significantly different from zero (at 95\% confidence level) so $\alpha$ values of either sign can occur due to statistical sampling from the population from which Figure 2 is drawn. Lastly, the apparent non-linearity of the ablationtemperature relation "twists" the regression line and forces $\alpha$ towards the negative.

\section{DEGREE-DAY FACTORS}

Reported positive degree-day factors for ice and snow on various glaciers are summarized in Table 2 . There is a broad agreement in degree-day factors for ice except for a high value of $13.8 \mathrm{~mm} \mathrm{~d}^{-1}{ }^{\circ} \mathrm{C}^{-1}$ found in Spitsbergen by Schytt (1964). Snow melt has a lower positive degree-day factor than ice melt. Similar degree-day factors to those in Table 2 were found on Nordbogletscher for ice and snow, i.e. 7.2 and $2.5 \mathrm{mmd}^{1}{ }^{\circ} \mathrm{C}^{-1}$ (Braithwaite and Olesen, 1988). However, to further complicate things, Braithwaite and Olesen (1993) found different (ice) degree-day factors on Qamanârssûp sermia for different seasons: $9.4 \mathrm{~mm} \mathrm{~d}^{-1} \mathrm{C}^{-1}$ for September-May, 7.5 for JuneAugust and 7.9 for the whole year.

The variation of positive degree-day factors from Greenland is illustrated in Figure 3 where ice ablation is

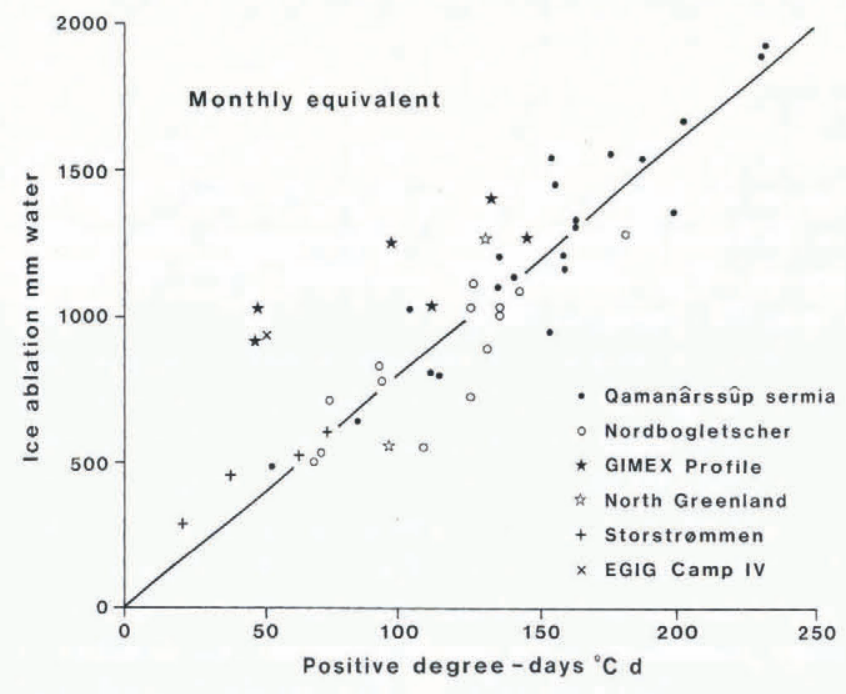

Fig. 3. Monthly equivalent ice ablation on the Greenland ice sheet versus positive degree days for various sites. The straight line denotes a positive degree-day factor of $8 \mathrm{~mm}$ $d^{1}{ }^{\circ} C^{-1}$ (Huybrechts and others, 1991).

plotted against positive degree-day sums from a number of recent studies. These are: Qamanârssûp sermia (21 months) and Nordbogletscher (14 months) (Braithwaite and Olesen, 1989); GIMEX profile east of Sondre Strømfjord (Bintanja and others, 1990; van de Wal, 1992); Storstrømmen profile in northeast Greenland (Boggild and others, 1994); EGIG Camp IV near the equilibrium line in West Greenland (Ambach, 1963); and and Hans Tavsen ice cap, North Kronprins Christian Land Greenland (Konzelmann and Braithwaite, 1995). The first two cases refer to monthly values between June and August, but periods of measurement are irregular (19-53 d in summer) for the other cases. In the interests of comparing like with like, the latter data have therefore been adjusted in both $x$ and $y$ coordinates to monthly equivalents (for $31 \mathrm{~d}$ ) before plotting.

The straight line in Figure 3 represents the degree-day factor of $8 \mathrm{~mm} \mathrm{~d}^{-1}{ }^{\circ} \mathrm{C}^{-1}$ assumed by Huybrechts and others (1991). The data from Qamanârssûp sermia and

Table 2. Positive degree-day factors for ice and snow ablation on glaciers. Units are $\mathrm{mm}^{-1}{ }^{\circ} \mathrm{C}^{-1}$

\begin{tabular}{|c|c|c|c|}
\hline Ice & Snow & & Reference \\
\hline $5.0-7.0$ & & Swiss glaciers & Kasser (1959) \\
\hline 13.8 & & Spitsbergen & Schytt (1964) \\
\hline 6.3 & & Store Supphellebre & Orheim $(1970)$ \\
\hline & 5.4 & Gr. Aletschgletscher & Lang and others (1976) \\
\hline $5.5 \pm 2.3$ & & Norway & Braithwaite (1977) \\
\hline $6.3 \pm 1.0$ & & Arctic Canada & Braithwaite (1981) \\
\hline 6.0 & 3.0 & Franz Josef Glacier & Woo and Fitzharris (1992) \\
\hline 7.7 & 5.7 & Sátujökull & Jóhannesson and others (1993) \\
\hline 6.4 & 4.4 & Nigardsbreen & Jóhannesson and others (1993) \\
\hline 6.0 & 4.5 & Alfotbreen & Laumann and Reeh (1993) \\
\hline 5.5 & 4.0 & Nigardsbreen & Laumann and Reeh (1993) \\
\hline 5.5 & 3.5 & Hellstugubreen & Laumann and Reeh (1993) \\
\hline
\end{tabular}


Nordbogletscher are evenly scattered around this straight line because it was actually based on these values (Reeh, 1991). The other points generally lie above the line, indicating higher degree-day factors. Especially interesting are the highest degree-day factors for GIMEX profile, i.e. 22.2 and $20.1 \mathrm{~mm} \mathrm{~d}^{-1}{ }^{\circ} \mathrm{C}^{-1}$ (Bintanja and others, 1990;

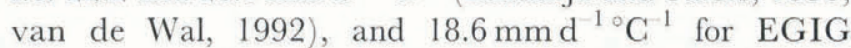
Camp IV (Ambach, 1963).

There is obviously a relation between ablation and positive degree-days but no indication of a single universal value. The error in measuring monthly ablation, and thereby positive degree-day factor, is only about $\pm 10 \%$ so the outliers in Figure 3 cannot be dismissed as error deviations from a general rule. These few data may be more representative of large parts of the ice sheet than outlet glaciers like Qamanârssûp sermia and Nordbogletscher, e.g. the upper ablation area (GIMEX profile and EGIG Camp IV) and northerly margin (Storstrommen and Kronprins Christian Land). It is encouraging that large positive degree-day factors only occur with lower positive degree days (lower temperatures) and there is no sign of high values at high temperatures. The high degreeday factor found in Spitsbergen by Schytt (1964) agrees with this pattern as it refers to low temperatures, i.e. $30 \mathrm{deg} \mathrm{d}$ for a monthly mean temperature of about $-1.4^{\circ} \mathrm{C}$.

\section{ENERGY-BALANCE MODELLING}

Daily ablation $a_{t}{ }^{*}$ is also calculated from the energybalance equation:

$$
a_{t}^{*}=\operatorname{shf}_{t}+\operatorname{lhf}_{t}+\operatorname{swr}_{t}+\operatorname{lwr}_{t}
$$

where $\operatorname{shf}_{t}$ and $\mathrm{lhf}_{t}$ are turbulent sensible- and latent-heat fluxes, and $\operatorname{swr}_{t}$ and $\operatorname{lwr}_{t}$ are the short-wave and longwave radiation fluxes, respectively. Heat conduction into the glacier surface and the specific heat of rainfall are neglected compared with the above terms. For convenience, all terms are expressed in ablation units, i.e. $\mathrm{mm} \mathrm{d}^{-1}$, numerically equivalent to $\mathrm{kg} \mathrm{m}^{-2} \mathrm{~d}^{-1}$.

On the basis of energy-balance studies in both the ablation and accumulation areas of the Greenland ice sheet (Ambach, 1963, 1977), Ambach (1986) proposed simple formulations for the turbulent-heat fluxes. The sensible-heat flux is calculated from temperature and wind speed:

$$
\operatorname{shf}_{t}=K_{\mathrm{S}} P \Delta T_{t} V_{t}
$$

where $P$ is atmospheric pressure (assumed constant for any site), $\Delta T_{t}$ is the difference between daily mean air temperature above the glacier and the temperature of the glacier surface, and $V_{t}$ is the daily mean wind speed. $K_{\mathrm{S}}$ is an exchange coefficient that, for a Prandtl-type neutral boundary layer with logarithmic profiles for wind speed and temperature, is given by:

$$
K_{\mathrm{S}}=c_{\mathrm{p}} \mathrm{k}^{2} \rho_{0} /\left[P_{0} \ln \left(z / z_{0 \mathrm{w}}\right) \ln \left(z / z_{0 \mathrm{~T}}\right)\right]
$$

where $c_{\mathrm{p}}$ is the specific heat of air at constant pressure $\left(1005 \mathrm{~J} \mathrm{~kg}^{-1}{ }^{\circ} \mathrm{C}^{-1}\right), \mathrm{k}$ is von Karman's constant $(0.41), \rho_{0}$ is the standard density of air $\left(1.29 \mathrm{~kg} \mathrm{~m}^{-3}\right), P_{0}$ is the standard atmospheric pressure $\left(1.013 \times 10^{5} \mathrm{~Pa}\right), z$ is the instrument height $\left(2 \mathrm{~m}\right.$ in the present case) and $z_{0 \mathrm{w}}$ and $z_{0 \mathrm{~T}}$ are the roughness parameters for logarithmic wind and temperature profiles, respectively. The latent-heat flux is calculated from vapour-pressure and wind-speed data by:

$$
\operatorname{lhf}_{t}=K_{\mathrm{L}} \Delta e_{t} V_{t}
$$

where $\Delta e_{t}$ is the difference between the vapour pressure of the air and the saturation vapour pressure at the glacier surface $(611 \mathrm{~Pa})$. For the same assumptions as before, the exchange coefficient is given by:

$$
K_{\mathrm{L}}=L \mathrm{k}^{2} \rho_{0} 0.623 /\left[P_{0} \ln \left(z / z_{0 \mathrm{w}}\right) \ln \left(z / z_{0 \mathrm{e}}\right)\right]
$$

where $L$ is the latent heat of evaporation or sublimation as appropriate $\left(2.514 \times 10^{6}\right.$ or $\left.2.849 \times 10^{6} \mathrm{~J} \mathrm{~kg}^{-1}\right)$ and $z_{0 \mathrm{e}}$ is the roughness parameter for the logarithmic profile of vapour pressure. The glacier surface is initially assumed to be melting for each day of the simulations but the surface temperature is re-calculated if it is not possible to get a positive energy balance. Ambach (1986) assumes wind roughness lengths of $2 \times 10^{-3}$ and $1 \times 10^{-4} \mathrm{~m}$ for ice and snow surfaces, respectively, and roughness lengths for temperature and water vapour are $6 \times 10^{-6} \mathrm{~m}$ for both ice and snow surfaces. Similar equations to (10) and (12) have been used for modelling turbulent fluxes in snowmelt studies (Wilson, 1941).

The short-wave radiation flux in $\mathrm{mm} \mathrm{d}^{-1}$ is:

$$
\operatorname{swr}_{t}=(1-r) g_{t} / 0.335
$$

where $r$ is albedo, $g_{t}$ is short-wave insolation $\left(\mathrm{MJ} \mathrm{m}^{-2} \mathrm{~d}^{-1}\right)$, and $0.335 \mathrm{MJ} \mathrm{kg}^{-1}$ is latent heat of fusion. Daily insolation was measured at both stations from 1981 onwards while for earlier years it was estimated from sunshine duration (Braithwaite and Olesen, 1990a). Ambach (1986) assumes albedos of 0.3 and 0.7 for ice and snow surfaces, respectively. The long-wave radiation flux in $\mathrm{mm} \mathrm{d}^{-1}$ is given by:

$$
\operatorname{lwr}_{t}=\left[\varepsilon^{*} \sigma\left(273.15+T_{t}\right)^{4}-27.35\right] / 0.335
$$

where $\varepsilon^{*}$ is the effective emissivity of the cloudy sky, $\sigma$ is the Stefan-Boltzmann constant, 273.15 adjusts the air temperature to absolute temperature and $27.35 \mathrm{MJ} \mathrm{m}^{-2}$ $\mathrm{d}^{-1}$ is the outgoing long-wave radiation from the melting glacier surface. According to measurements on Axel Heiberg Island, northern Canada (Ohmura, 1981), the effective emissivity is:

$$
\varepsilon^{*}=8.733 \times 10^{-3}\left(1+k n_{t}\right)\left(273.15+T_{t}\right)^{0.8}
$$

where $k$ is a constant (assumed equal to 0.26 here) and $n_{t}$ is daily sunshine duration. Ohmura (1981) suggests that the temperature-dependence of effective emissivity accounts for the increase in absolute humidity with temperature.

Parallel with the ablation measurements, the nature of the glacier surface (ice or snow) was noted and is used to choose the appropriate albedo and roughness parameters. The glacier surface is ice for most days in both data sets, but traces of snow do occur for short periods with colder temperatures. 
The difference between observed ablation $a_{t}$ and calculated ablation $a_{t}{ }^{*}$ is $\mathrm{d}_{t}=\left(a_{t}-a_{t}{ }^{*}\right)$ and accounts for errors in both the data and the model. Defined in this way, $\mathrm{d}_{t}$ has the nature of an extra (unspecified) energybalance component, and statistics involving $\mathrm{d}_{t}$ are a useful check on the accuracy of the data and the model.

The calculated energy balance is summarized in Table 3 by means and standard deviations of the various terms. In both locations, short-wave radiation is the major energy source followed by sensible-heat flux, while long-wave radiation is a heat sink and latent-heat flux is, on average, small. In conventional terms, radiation accounts for about two-thirds of ablation energy and turbulence accounts for the other third.

Table 3. Observed ablation and calculated energy balance for two sites, West Greenland. Units are $\mathrm{mmd}^{-1}$. From Braithwaite and Olesen (1990a)

\begin{tabular}{lcc}
\hline & NBG & QAM \\
& (Stake 53) & $\begin{array}{c}\text { (Stake 751) } \\
\text { Latitude }\end{array}$ \\
\hline Altitude (m a.s.l.) & $61^{\circ} 28^{\prime} \mathrm{N}$ & $64^{\circ} 28^{\prime} \mathrm{N}$ \\
Days & 880 & 790 \\
Observed ablation & 415 & 512 \\
Sensible heat & $28.7 \pm 20.3$ & $41.5 \pm 29.1$ \\
Latent heat & $8.3 \pm 9.6$ & $16.0 \pm 13.4$ \\
Short-wave radiation & $0.6 \pm 4.8$ & $-1.5 \pm 8.9$ \\
Long-wave radiation & $28.7 \pm 13.6$ & $33.1 \pm 16.2$ \\
Error & $-8.3 \pm 6.1$ & $-6.4 \pm 5.8$ \\
& $-0.5 \pm 13.6$ & $0.4 \pm 18.9$ \\
\hline
\end{tabular}

There are substantial errors on a day-to-day basis in the energy-balance modelling, expressed by standard deviations of \pm 13.6 and $\pm 18.9 \mathrm{~mm} \mathrm{~d}^{-1}$ for $\mathrm{d}_{t}$. Braithwaite and Olesen (1990a) suggest that the main sources of error are (1) errors of \pm 10 to $\pm 20 \mathrm{~mm} \mathrm{~d}^{-1}$ in measuring daily ablation $a_{t}$, (2) variations in ice albedo due to dust, surface water and formation of 'weathering crust', (3) underestimation of sensible-heat flux under föhn-type weather, which more than offsets the error involved in assuming neutral stability, and (4) neglect of heat conduction into the ice. The first is probably the largest source of random error. This is because errors in the energy-balance model $\left(\mathrm{d}_{t}\right)$ and regression model $\left(e_{t}\right)$ have nearly identical standard deviations, and the error in measuring ablation is the only source of error common to both approaches.

\section{ENERGY BALANGE AND DEGREE-DAY FACTORS}

The positive degree-day factors for observed ablation at Nordbogletscher (415d) and Qamanârssûp sermia (512d) are 7.53 and $8.19 \mathrm{mmd}^{1}{ }^{\circ} \mathrm{C}^{-1}$, respectively. Positive degreeday factors for ablation $a_{t}{ }^{*}$ calculated with the energy balance are remarkably similar to the previous ones with values of 7.67 and $8.12 \mathrm{~mm} \mathrm{~d}^{-1}{ }^{\circ} \mathrm{C}^{-1}$, respectively, for the two sites. The slightly higher degree-day factor for
Qamanârssûp sermia compared with Nordbogletscher is thereby demonstrated for both observed and simulated ablation, and is therefore explained by the energy balance.

The above simulations used the observed condition of the glacier surface each day to choose ice or snow parameters as appropriate. Further simulations were made where the observed surface conditions were overridden and the energy balance was calculated as if the glacier surface were ice or snow for every day, with all other variables left as before. These experiments imply that surface conditions can be changed without changing other climate variables although there may be subtle feedbacks between surface conditions and climate variables so the experiment cannot be totally realistic.

Positive degree-day factors for hypothetical ice and snow surfaces are shown in Table 4 together with those for observed ablation and for the actual surface. Degree-day factors for ice surfaces are somewhat larger than for actual surfaces, indicating that even the traces of snow that occur during the summer cause lower degree-day factors. (Note that the values in Table 4 are not statistically independent and confidence intervals are not calculated.) Braithwaite and Olesen (1989) interpreted positive degree-day factors for observed ablation as essentially describing ice surfaces, but Table 4 shows that degree-day factors for actual surfaces are slightly lower than degreeday factors for (hypothetical) ice surfaces. The difference between degree-day factors at Qamanârssûp sermia and Nordbogletscher is less for ice surfaces than for actual surfaces, suggesting that the lower degree-day factor at Nordbogletscher (for the actual surface) is partly due to the higher frequency of traces of snow.

The effect of replacing ice surfaces in the model with snow is even more dramatic with positive degree-day factors of only $36-44 \%$ of the corresponding values for ice surfaces.

Table 4. Degree-day factors for observed data and for ablation simulated by the energy-balance model. Units are mmd $^{-1}{ }^{\circ} \mathrm{C}^{-1}$

$\begin{array}{cc}\text { NBG } & \text { QAM } \\ \text { (Stake 53) } & \text { (Stake 751) }\end{array}$

\begin{tabular}{lcc}
\hline Days & 415 & 512 \\
Observed data & 7.53 & 8.19 \\
Simulated: & & \\
- Ice surface & 8.07 & 8.32 \\
- Actual surface & 7.67 & 8.12 \\
- Snow surface & 2.89 & 3.67 \\
\hline
\end{tabular}

\section{EXPERIMENTS WITH THE ENERGY-BALANCE MODEL}

Experiments were made by re-running the energybalance model under different conditions to those measured. The main experiments were to assess (1) the effects of temperature changes and (2) the relative effects of albedo and turbulence. 
In the first experiment, the model was re-run with all daily temperatures shifted by -5 to $+5{ }^{\circ} \mathrm{C}$ in $1{ }^{\circ} \mathrm{C}$ steps, thus simulating a change in mean temperature. Wind speed, sunshine duration and global radiation were left unchanged for each day, and vapour pressure was adjusted to keep the relative humidity for each day the same as it was before the temperature change in the model.

The ablation is calculated from the energy balance for every day (415 d at Nordbogletscher, $512 \mathrm{~d}$ at Qamanârssûp sermia), and the mean ablation is then calculated for the whole sample. Figure 4 is obtained by plotting curves through the points representing mean ablation rate versus summer temperature for both ice and snow surfaces. Summer temperature is the mean of June, July and August monthly temperatures. Present climate conditions are represented by values of 3.7 and $5.0^{\circ} \mathrm{C}$, respectively, at Nordbogletscher and Qamanârssûp sermia. The ablation-

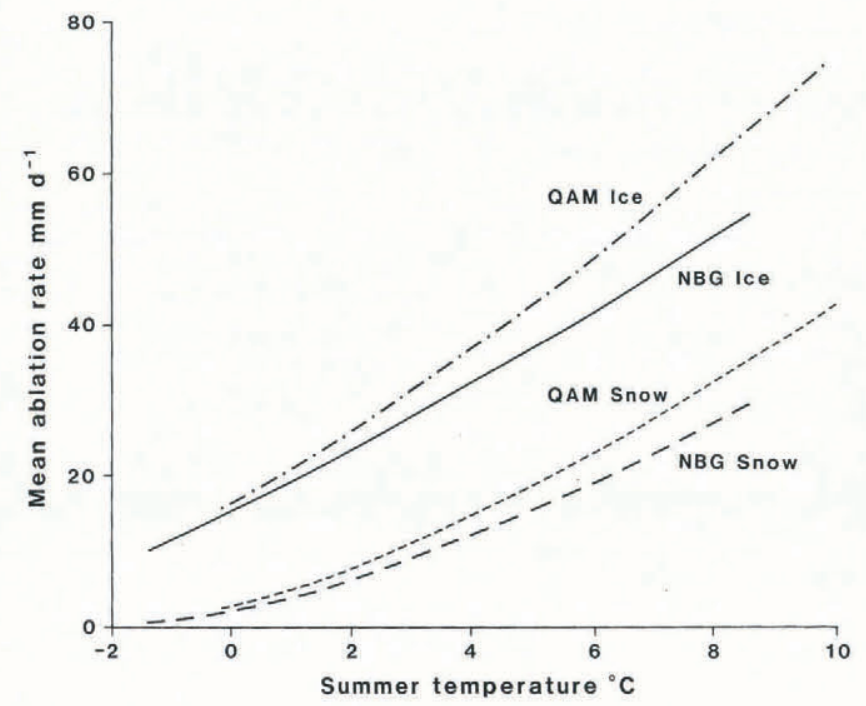

Fig. 4. Mean ablation rate for June-August as a function of summer (June-August) mean temperature at Nordbogletscher and Qamanârssûp sermia. (Simulation.)

temperature curve is non-linear in agreement with Gutersohn (1936), Loewe (1971), Krenke (1975) and Ohmura and others (1992), but these authors suggest power-law relations while the present curves tend to straight lines at higher temperatures as the frequency of below-freezing temperatures is reduced.

Positive degree-day factors (Fig. 5) are calculated from the simulated-ablation values (Fig. 4) by dividing them with the appropriate positive degree-day sums. The degree-day factors for simulated ice ablation (model albedo $=0.3$ ) are high for low temperatures and fall rapidly with rising temperature as predicted by Ambach (1988) and by Equation (6) with positive $\alpha$. The degreeday curves for simulated snow ablation (model albedo $=0.7$ ) show the opposite behaviour and, from Equation (6), it is tempting to ascribe this to negative values of $\alpha$ for snow.

The effect of albedo variations on positive degree-day factors at Qamanârssûp sermia (Fig. 6) is simulated by re-running the model with different values of model albedo while keeping the surface roughness the same as for ice. Results from Nordbogletscher (not shown) are

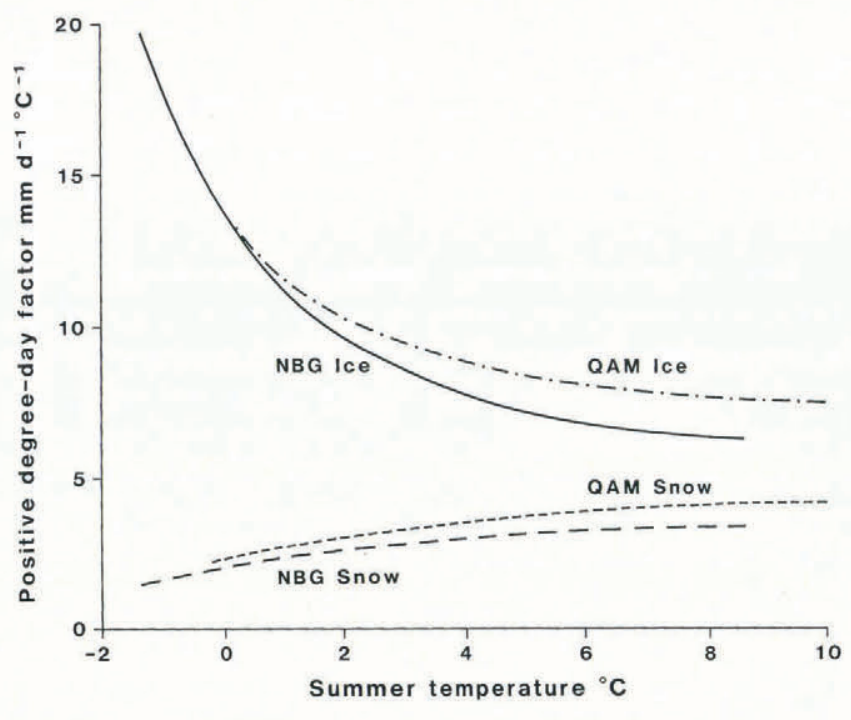

Fig. 5. Positive degree-day factors for snow and ice as a function of summer (June-August) mean temperature at Nordbogletscher and Qamanârssûp sermia. (Simulation.)

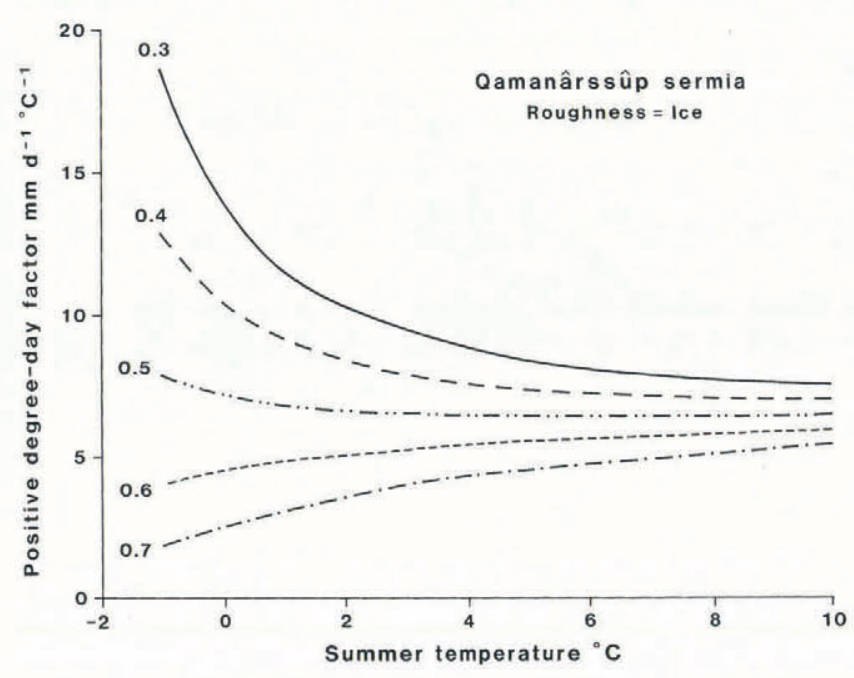

Fig. 6. Effect of albedo variations 0.3-0.7 on positive degree-day factor at Qamanârssûp sermia. Surface roughness is for ice. (Simulation.)

qualitatively similar. The greatest effect of albedo variations is at lower temperatures, where the short-wave radiation is largest in relation to ablation, and is reduced at higher temperatures. In terms of Equation (6), albedo affects the $\alpha$ factor (intercept).

The effect of turbulence variations on positive degreeday factors at Qamanârssûp sermia (Fig. 7) is simulated by re-running the model with the turbulent sensible- and latent-heat flux terms re-scaled with factors of 0.5 to 1.5 while albedo is kept the same as for ice $(0.3)$. The scaling factors are equivalent to adjusting the mean wind speed by up to $\pm 50 \%$ or to changing the surface roughness. Results from Nordbogletscher (not shown) are qualitatively similar. The greatest effect of turbulence variations is at higher temperatures, where the turbulent fluxes are largest in relation to ablation. In terms of Equation (6), turbulence affects the $\beta$ factor (slope). 


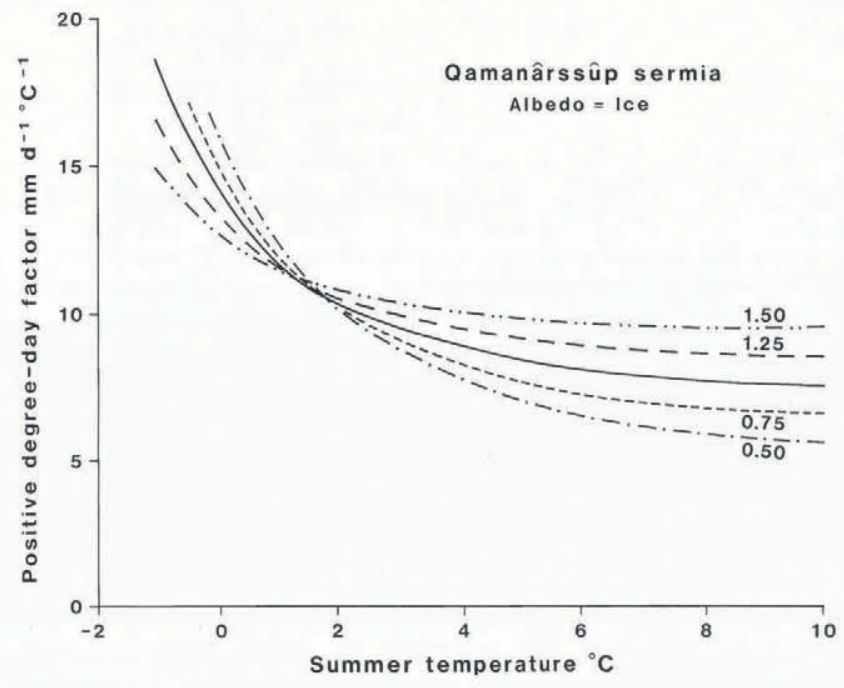

Fig. 7. Effect of variations in turbulence on positive degree-day factor at Qamanârssup sermia. Wind speed is multiplied by 0.5-1.5. Albedo is for ice. (Simulation.)

\section{DISGUSSION}

The scatter of points in Figure 3 shows that a constant positive degree-day factor of $8 \mathrm{~mm} \mathrm{~d}^{-1}{ }^{\circ} \mathrm{C}^{-1}$ for melting ice (Reeh, 1991; Huybrechts and others, 1991) can be only approximately correct and must be used with caution. Positive degree-day factors can be greater than assumed, especially at the lower temperatures typical of the upper ablation area (GIMEX profile and EGIG Camp IV) and in the more northerly parts of the ice sheet (Storstrommen and Kronprins Christian Land) but there is no sign of high degree-day factors at high temperatures. This means that the total runoff from the Greenland ice sheet might be a few tenths greater than calculated by Huybrechts and others (1991).

According to present experiments, variations in positive degree-day factors (Fig. 3) could be due to variations in albedo and turbulence, in agreement with van de Wal (1992, p.27). Low albedo may explain the very high values of positive degree-day factor at lower temperatures, but if this is correct the high degree-day factors decrease as temperature increases.

Remaining uncertainties about degree-day factors can be reduced by (1) better knowledge of ablation variations at greater elevations and in remoter parts of the ice sheet, where there are still too few data, (2) better knowledge of albedo variations, and (3) better understanding of turbulence conditions. With respect to (1), ablation measurements are planned for 1994 95 on the Hans Tavsen Ice Cap in North Greenland (Fig. 1), which should give the opportunity of studying ablation under extreme conditions. With respect to $(2)$, progress is being made towards accurate measurement of clear-sky albedo by satellite (Haefliger and others, 1993) and maps of albedo variations may be available soon over large parts of the ice sheet. With respect to (3), detailed boundary-layer studies have been made recently (Oerlemans and Vugts, 1993; Ohmura and others, in press) and these may give a better understanding of turbulence, especially in the stable boundary layer that is common over the ice sheet.
With better understanding of ablation conditions, albedo and turbulence, it should be possible to include a variable positive degree-day factor in future ice-sheet models. At the same time, better understanding in the areas mentioned will also make it easier to apply energybalance models in the future.

\section{CONCLUSIONS}

Positive degree-day factors, linking ice ablation to positive degree-day sums, are generally larger than the $8 \mathrm{~mm}$ $\mathrm{d}^{-1}{ }^{\circ} \mathrm{C}^{-1}$ assumed by Huybrechts and others (1991), and their estimate of runoff from the Greenland ice sheet may be somewhat too small. The energy-balance model simulates realistic positive degree-day factors for ice ablation and shows that the positive degree-day factor for snow is less than half that for ice. Even occasional traces of snow during the summer significantly lower degree-day factors. Positive degree-day factors vary with mean temperature, albedo and turbulence. There is evidence of high positive degree-day factors only at lower temperatures, and not at high temperatures. Remaining uncertainties in degree-day factors can be reduced by (1) ablation data from parts of the ice sheet where there are still too few data, (2) better general knowledge of albedo variations, and (3) better understanding of turbulence conditions.

\section{ACKNOWLEDGEMENTS}

This paper is published by permission of the Geological Survey of Greenland (GGU) and was prepared under contract EV5V-CT91-0051 from the European Community, coordinated by the Climate Research Unit, University of East Anglia, U.K. Some of the data in Figure 3 were collected under contract EPOC-CT90-0015 from the European Community, coordinated by the Department of Geography, Coventry University, U.K. The ideas were discussed in graduate seminars in the Department of Geography, Swiss Federal Institute of Technology, Zürich, in November 1993 when the author was a guest of Professor A. Ohmura (ETH grant No. 0-04-509-93). The drawings were prepared by $\mathrm{G}$. Hansen (GGU).

\section{REFERENCES}

Ambach, W. 1963. Untersuchungen zum Energieumsatz in der Ablationszone des grönländischen Inlandeises. CAMP IV-EGIG, $69^{\circ} 40^{\prime} 05^{\prime \prime} \mathrm{N}, 49^{\circ} 37^{\prime} 58^{\prime \prime}$ W). Medd. Gronl., 174(4).

Ambach, W. 1977. Untersuchungen zum Energieumsatz in der Akkumulationszone des grönländischen Inlandeises. Medd. Gronl., $187(7)$.

Ambach, W. 1986. Nomographs for the determination of meltwater from snow- and ice surfaces. Berichte des Wissenschaftlich Medizinischen Vereins in Innsbruck, 73, 7-15.

Ambach, W. 1988. Heat balance characteristics and ice ablation, western EGIG-profile, Greenland. In Thomsen, T., H. Sogaard and R.J. Braithwaite, eds. Applied hydrology in the development of northern basins. Copenhagen, Danish Society for Arctic Technology, 59-70.

Arnold, K. C. and D. K. MacKay. 1964. Different methods of calculating mean daily temperatures, their effects on degree-day totals in the high Arctic and their significance to glaciology. Geogr. Bull., 21, 123-129.

Bintanja, R. and 9 others. Unpublished. Greenland Ice Margin EXperiment (GIMEX). Utrecht, Utrecht University. (GIMEX-90 field report.) 
Bøggild, C. E., N. Reeh and H. Oerter. 1994. Modelling ablation and mass-balance sensitivity to climate change of Storstrømmen, northeast Greenland. Global and Planetary Change, 9, 7990.

Braithwaite, R.J. 1977. Air temperature and glacier ablation - a parametric approach. (Ph.D. thesis, McGill University.)

Braithwaite, R.J. 1981. On glacier energy balance, ablation and air temperature. 7. Glaciol., 27(97), 381-391.

Braithwaite, R.J. 1985. Calculation of degree-days for glacier-climate research. Z. Gletscherkd. Glazialgeol., 20, 1984, 1-8.

Braithwaite, R.J. and O.B. Olesen. 1985. Ice ablation in West Greenland in relation to air temperature and global radiation. Z. Gletscherkd. Glazialgeol., 20, 1984, 155-168.

Braithwaite, R.J. and O.B. Olesen 1988. Winter accumulation reduce summer ablation on Nordbogletscher, south Greenland. Z. Gletscherkd. Glazialgeol., 24(1), 21-30.

Braithwaite, R. J. and O. B. Olesen. 1989. Calculation of glacier ablation from air temperature, West Greenland. In Oerlemans, J., ed. Glacier fluctuations and climatic change. Dordrecht, Kluwer Academic Publishers, $219-233$.

Braithwaite, R.J. and O.B. Olesen. 1990a. A simple energy-balance model to calculate ice ablation at the margin of the Greenland ice sheet. f. Glaciol., 36(123), 222-228.

Braithwaite, R.J. and O.B. Olesen. 1990b. Response of the energy balance on the margin of the Greenland ice sheet to temperature changes. 7. Glaciol., 36(123), 217-221.

Braithwaite, R.J. and O.B. Olesen. 1993. Seasonal variation of ice ablation at the margin of the Greenland ice sheet and its sensitivity to climate change, Qamanârssûp sermia, West Greenland. 7. Glaciol., 39 (132), 267-274.

Finsterwalder, S. and H. Schunk. 1887. Der Suldenferner. Zeitschrift des Deutschen und Österreichischen Alpenvereins, 18, 7289.

Gutersohn, H. 1936. Ablation und Abfluss; Untersuchungen an Gletschern der Schweizer Alpen. International Association of Scientific Hydrology Publication 23, 207-222.

Haefliger, M., K. Steffen and C. Fowler. 1993. AVHRR surface temperature and narrow-band albedo comparison with ground measurements for the Greenland ice sheet. Ann. Glaciol., 17, 49-54.

Hoinkes, H. and R. Steinacker. 1975. Hydrometeorological implications of the mass balance of Hintereisferner, $1952-53$ to $1968-69$. International Association of Hydrological Sciences Publication 104 (General Assembly of Moscow 1971 - Snow and Ice), 144-149.

Huybrechts, P., A. Letréguilly and N. Reeh. 1991. The Greenland ice sheet and greenhouse warming. Palaeogeogr., Palaeoclimatol., Palaeoecol., $89(4), 399-412$

Jóhannesson, T., O. Sigurd̀sson, T. Laumann and M. Kennett. 1993. Degreeday glacier mass balance modelling with applications to glaciers in Iceland and Nonway. Reykjavík, Orkustofnun. (Nordic Hydrological Programme Report 33.)

Kasser, P. 1959. Der Einfluss von Gletscherrückgang und Gletschervorstoss auf den Wasserhaushalt. Wasser- und Energiewirtschaft, 51(6), 155-168.

Konzelmann, T. and R.J. Braithwaite. 1995. Variations of ablation, albedo and energy balance at the margin of the Greenland ice sheet,
Kronprins Christian Land, eastern North Greenland. f. Glaciol. 41(137), 174-182

Krenke, A. N. 1975. Climatic conditions of present-day glaciation in Soviet Central Asia. International Association of Hydrological Sciences Publication 104 (General Assembly of Moscow 1971 - Snow and Ice), $30-41$.

Kuhn, M. 1987. Micro-meteorological conditions for snow melt. 7 Glaciol., 33 (113), 2426.

Kuusisto, E. 1984. Snow accumulation and snowmelt in Finland. Helsinki, National Board of Waters. Water Research Institute. (Publication 55.)

Lang, H., B. Schädler and G. Davidson. 1977. Hydroglaciological investigations on the Ewigschneefeld-Gr. Aletschgletscher. Z. Gletscherkd. Glazialgeol., 12(2), 1976, 109-124.

Laumann, T. and N. Reeh. 1993. Sensitivity to climate change of the mass balance of glaciers in southern Norway. 7. Glaciol., 39(133), 656-665.

Letréguilly, A., P. Huybrechts and N. Reeh. 1991. Steady-state characteristics of the Greenland ice sheet under different climates. J. Glaciol., 37 (125), 149-157.

Loewe, F. 1971. Considerations on the origin of the Quaternary ice sheet of North America. Arct. Alp. Res., 3 (4), 331-344.

Oerlemans, J. and H.F. Vugts. 1993. A meteorological experiment in the melting zone of the Greenland ice sheet. Bull. Am. Meteorol. Soc., 74(3), 355-365.

Ohmura, A. 1981. Climate and energy balance on Arctic tundra. Axel Heiberg Island. Canadian Archcipelago, spring and summer 1969, 1970 and 1972. Zürcher Geogr. Schr., 3.

Ohmura, A., P. Kasser and M. Funk. 1992. Climate at the equilibrium line of glaciers. 7. Glaciol., 38(130), 397-411.

Ohmura, A. and 8 others. In press. Energy balance on the equilibrium line of the Greenland ice sheet. International Association of Hydrological Sciences Publication (Symposia of Yokohama 1993 - Snow Cover and its Interactions with Climate and Ecosystems; Processes of Mass and Energy Exchange between the Atmosphere and Polar Surface).

Olesen, O.B. and R.J. Braithwaite. 1989. Field stations for glacier climate research, West Greenland. In Oerlemans, J., ed. Glacier fluctuations and climatic change. Dordrecht, Kluwer Academic Publishers, 207-218.

Orheim, O. 1970. Glaciological investigations of Store Supphellebre, west-Norway. Nor. Polarinst. Skr. 151.

Quervain, M. de. 1979. Schneedeckenablation und Gradtag im Versuchsfeld Weissfluhjoch. Eid. Tech. Hochschule, Zürich. Versuchsanst. Wasserbau, Hydrol. Glaziol. Mitt. 41, 215-232.

Reeh, N. 1991. Parameterization of melt rate and surface temperature on the Greenland ice sheet. Polarforschung, 59(3), 1989, 113-128.

Schytt, V. 1964. Scientific results of the Swedish Glaciological Expedition to Nordaustlandet, Spitsbergen, 1957 and 1958. Geogr. Ann., 46 (3), 243-281.

Wal, R. van de. 1992. Ice and climate. (Ph.D. thesis, Utrecht University.) Wilson, W. T. 1941. An outline of the thermodynamics of snow-melt. Trans. Am. Geophys. Union, 1941, Part 1, $182-195$.

Woo, M.-k. and B.B. Fitzharris. 1992. Reconstruction of mass balance variations for Franz Josef Glacier, New Zealand, 1913-1989. Arct. Alp. Res., 24(4), 281-290. 